\title{
Scoping Review Efektivitas Centella Asiatica (L.) Urban dan Zat Aktifnya terhadap Proses Penyembuhan Luka pada Hewan Coba
}

\author{
Muhamad Al Hadi A A*, Herri S. Sastramihardja \\ Prodi Pendidikan Kedokteran, Fakultas Kedokteran, Universitas Islam \\ Bandung, Indonesia. \\ *alatas.hadi97@gmail.com, herri.sastramihardja@unisba.ac.id
}

\begin{abstract}
Wound occur due to tissue damage of the skin structure. When a wound occurs, the body will go through a wound healing process. The Centella asiatica (L.) Urban plant is an alternative treatment in accelerating wound healing because it contains asiaticoside which can increase fibroblast proliferation, increase collagen synthesis and plays a role in angiogenesis process by regulating the expression of VEGF, madecassoside which can increase collagen synthesis, and asiatic acid as an anti -inflammatory. This study aims to determine the effectiveness of Centella asiatica (L.) Urban on wound healing in experimental animals. This research used Scoping Review method by searched articles from Science Direct, Springer Link, and the Wiley Online Library. Articles matched the inclusion criteria were 619 articles and 611 articles were included in the exclusion criteria. There were eight articles fit into the PICOS criteria. This research was conducted in the period of SeptemberDecember 2020. The results of the study and analysis of eight articles, there were two articles that used the extract of Centella asiatica (L.) Urban directly on wounds, one article in the type of spray preparation, and five articles in wound dressings. All these articles showed that the administration of Centella asiatica (L.) Urban is effective against the wound healing process in experimental animals even though used with various types of preparations. The provision of Centella asiatica (L.) Urban has been proven effective in wound healing and the selection of the right type of preparation can increase the effectiveness of Centella asiatica (L.) Urban in healing wounds, this is due to the presence of asiaticoside, madecassoside and asiatic acid which can accelerate wound healing process.
\end{abstract}

Keywords: Centella Asiatica, Wound, Wound Healing.

Abstrak. Luka terjadi akibat adanya kerusakan jaringan pada struktur kulit. Saat luka terjadi, tubuh akan mengalami tahapan proses penyembuhan luka. Tanaman Centella asiatica (L.) Urban merupakan alternatif pengobatan dalam mempercepat penyembuhan luka karena mengandung asiaticoside yang dapat meningkatkan proliferasi fibroblas dan meningkatkan sintesis kolagen, serta beperan pada proses angiogenesis dengan meregulasi ekspresi VEGF, madecassoside yang dapat meningkatkan sintesis kolagen, dan asiatic acid sebagai anti-inflamasi. Penelitian ini bertujuan untuk mengetahui efektifitas Centella asiatica (L.) Urban terhadap penyembuhan luka pada hewan coba. Penelitian ini merupakan Scoping Review, dengan mencari artikel dari database Science Direct, Springer Link, dan Wiley Online Library. Artikel yang sesuai dengan kriteria inklusi sebanyak 619 artikel dan yang termasuk dalam kriteria ekslusi 611 artikel. Terdapat delapan artikel yang sesuai dengan kriteria PICOS. Penelitian ini dilakukan pada periode September-Desember 2020. Hasil telaah dan analisis dari delapan artikel, terdapat dua artikel yang menggunakan ekstrak Centella asiatica (L.) Urban secara langsung terhadap luka, satu artikel dalam jenis sediaan spray, dan lima artikel dalam sediaan balutan luka. Semua artikel tersebut menunjukkan bahwa pemberian Centella asiatica (L.) Urban efektif terhadap proses penyembuhan luka pada hewan coba meskipun digunakan dengan berbagai jenis sediaan. Pemberian Centella asiatica (L.) Urban terbukti efektif terhadap penyembuhan luka dan pemilihan jenis sediaan yang tepat dapat meningkatkan efektivitas Centella asiatica (L.) Urban dalam penyembuhan luka, hal tersebut dikarenakan adanya kandungan asiaticoside, madecassoside dan Asiatic acid yang dapat mempercepat proses penyembuhan luka.

Kata Kunci: Centella Asiatica, Luka, Penyembuhan Luka. 


\section{A. Pendahuluan}

Luka adalah kontinuitas struktur anatomi jaringan tubuh yang terputus. Kontinuitas struktur terputus tersebut dapat meliputi lapisan epitel kulit, jaringan subkutan, lemak, otot, atau bahkan struktur yang lebih dalam seperti pembuluh darah, saraf, dan tendon. Saat terjadi luka, kulit akan mengalami beberapa proses yang pada akhirnya berujung pada penyembuhan luka. Proses tersebut terdiri atas empat fase, yaitu fase hemostasis, fase inflamasi, fase proliferasi, dan fase remodeling. Fase hemostasis adalah reaksi tubuh untuk menghentikan perdarahan yang berlangsung selama beberapa menit hingga jam sesaat setelah terjadi luka. Fase inflamasi terjadi selama $0 \neg-3$ hari yang meliputi proses penghancuran semua debris dan pencegahan kolonisasi agen mikroba patogen oleh sistem imun. Fase proliferasi terjadi pada hari ke-3 hingga ke-20, yang ditandai dengan terjadinya pembentukan kolagen. Fase proliferasi meliputi tiga proses utama, yaitu neoangiogenesis, pembentukan kolagen, dan re-epitelisasi, yang ditandai dengan proliferasi sel keratinosit. Fase remodeling terjadi pada hari ke-21 hingga satu tahun dengan tujuan memaksimalkan struktur jaringan baru pengisi luka. Penelitian lain menyatakan bahwa fase remodeling ini sudah mulai terjadi pada minggu ke-2.1,2

Penatalaksanaan luka umumnya dilakukan dengan menggunakan normal saline dan iodium povidon $0,5 \%$ yang bersifat antibakteri. Penggunaan iodium povidon yang berlebihan dapat menimbulkan beberapa efek samping berupa dermatitis, bengkak, gatal serta rangsangan nyeri pada daerah sekitar luka.1 Timbulnya masalah efek samping pada penggunaan iodium povidon merupakan salah satu alasan diperlukan alternatif terapi, diantaranya melalui penggunaan obat tradisional. Indonesia termasuk salah satu negara yang penduduknya masih sering menggunakan tanaman tradisional dalam pengobatan suatu penyakit. Tanaman tradisional di Indonesia yang diketahui memiliki potensi sebagai obat salah satunya adalah pegagan (Centella asiatica (L.) Urban.3

Centella asiatica (L.) Urban atau pegagan merupakan tanaman liar yang memiliki khasiat sebagai tanaman obat dan termasuk tumbuhan tropis yang dapat tumbuh baik pada tanah yang agak lembap, tetapi cukup sinar matahari.4 Tanaman ini mengandung beberapa komponen yang bermanfaat bagi kesehatan, diantaranya triterpenoid dan minyak esensial. Kandungan triterpeinoid dalam tanaman pegangan terdiri dari asiatic acid, madecassoside dan asiaticoside. Asiatic acid memiliki efek sebagai antioksidan dan antiinflamasi; madecassoside sebagai antioksidan dan meningkatkan sintesis kolagen; dan asiaticoside yang dapat meningkatkan proliferasi fibroblast, sintesis kolagen serta pembentukan pembuluh darah baru. Keberadaan komponen tersebut diduga dapat berperan dalam mempercepat proses penyembuhan luka.5-8

Tujuan penelitian ini adalah untuk mengetahui efektivitas dan jenis sediaan Centella asiatica (L.) Urban terhadap proses penyembuhan luka pada hewan coba.

\section{B. Metodologi Penelitian}

Penelitian mengenai efektivitas Centella Asiatica (L.) Urban terhadap penyembuhan luka pada hewan coba dilakukan dengan metode scoping review. Prosedur penyusunan protokol dengan menggunakan metode PRISMA (preferred reporting items for systematic review and metaanalyses) dan pencarian data menggunakan Database ScienceDirect, SpringerLink, dan Wiley Online Library dengan kata kunci yang digunakan adalah Wound Healing AND Centella Asiatica. Skrining data dilakukan berdasar atas kriteria inklusi (artikel tahun 2010-2020, penelitian eksperimental, dan artikel dapat diakses penuh) dan kriteria eksklusi (ketidaksesuaian dengan Population, Intervention, Comparison, Outcome, Study serta data atau artikel penelitian yang duplikasi). Penilaian kualitas (kelayakan) dipilih berdasar kriteria PICOS (Population: hewan coba; Intervention: pemberian Centella Asiatica (L.) Urban; Comparison: tidak diberikan pengobatan atau pemberian obat selain Centella Asiatica (L.) Urban.; Outcome: proses penyembuhan; Study: eksperimental murni). 


\section{Hasil Penelitian dan Pembahasan}

Hasil

Hasil pencarian pada tiga database, yaitu ScienceDirect, SpringerLink, dan Wiley Online Library didapatkan artikel 8 internasional yang memenuhi kriteria inklusi dan eksklusi berdasar atas PICOS sehingga artikel tersebut telah memenuhi persyaratan untuk dianalisis. Hasil scoping review efektivitas Centella asiatica terhadap penyembuhan luka pada hewan coba dapat dilihat pada Tabel 4.1.
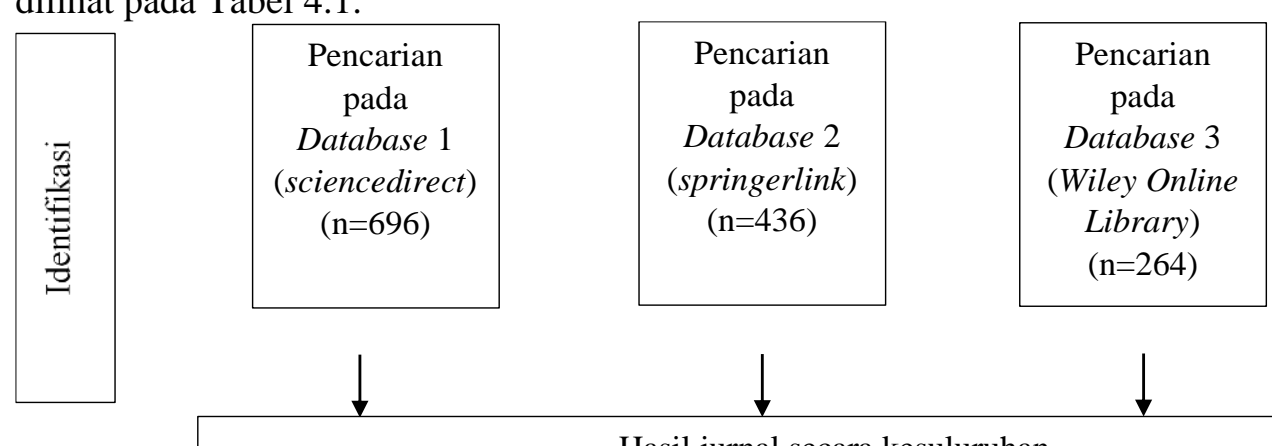

Hasil jurnal secara kesuluruhan

$$
(\mathrm{N}=1.396)
$$
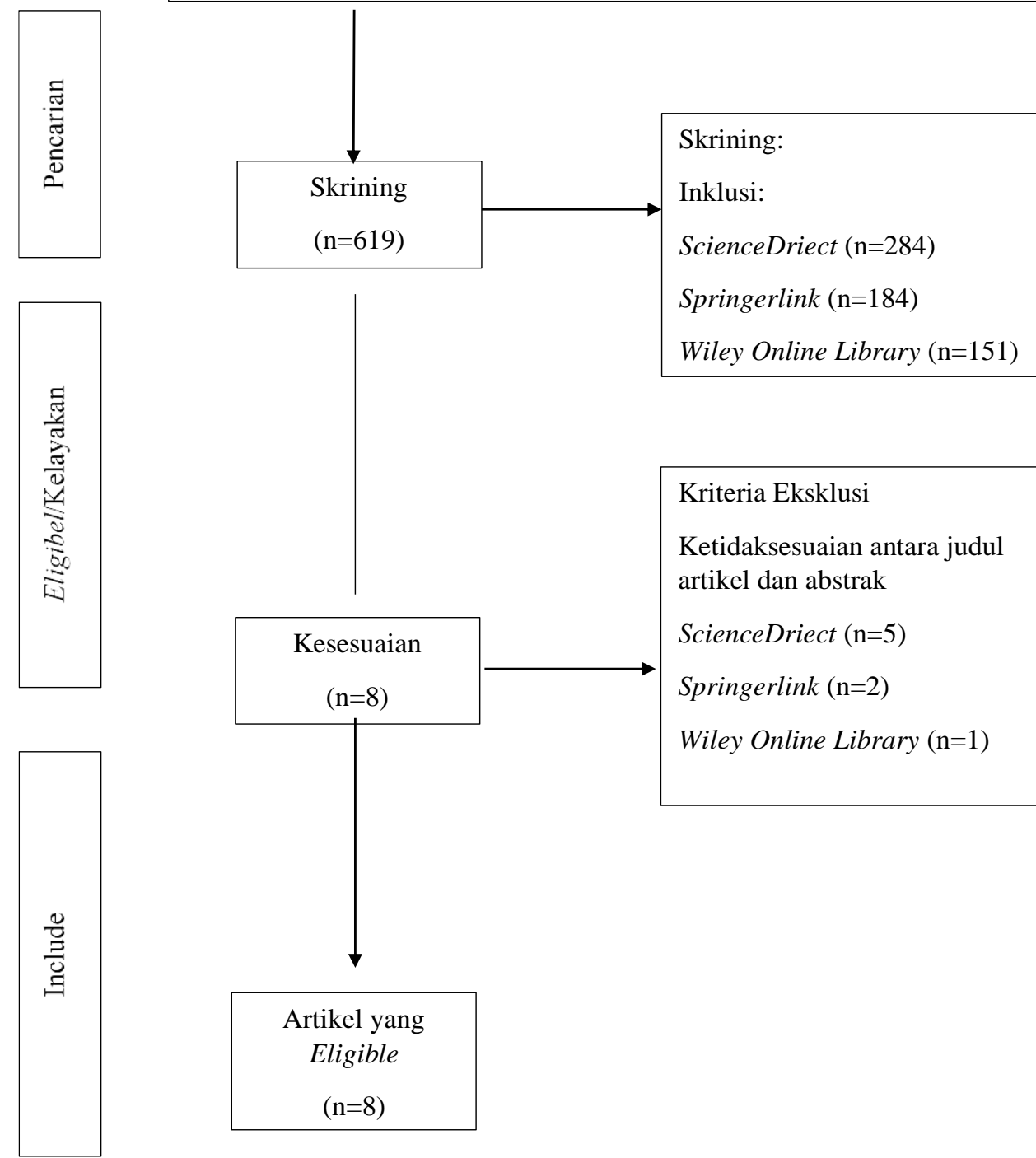

\section{Kriteria Eksklusi}

Ketidaksesuaian antara judul artikel dan abstrak

ScienceDriect $(\mathrm{n}=5)$

Springerlink $(\mathrm{n}=2)$

Wiley Online Library $(\mathrm{n}=1)$

Gambar 1. Diagram prisma 
Tabel 4.1 Kesimpulan Scoping Review Sesuai dengan Uji Efektivitas Centella Asiatica terhadap Proses Penyembuhan Luka pada Hewan Coba

\begin{tabular}{|c|c|c|c|c|}
\hline No & $\begin{array}{l}\text { Peneliti dan } \\
\text { Tahun } \\
\text { Penelitian }\end{array}$ & Judul & $\begin{array}{l}\text { Efektivitas } \\
\text { Centella } \\
\text { asiatica (L.) } \\
\text { Urban } \\
\text { terhadap luka }\end{array}$ & $\begin{array}{l}\text { Sediaan Centella } \\
\text { asiatica (L.) Urban } \\
\text { terhadap luka }\end{array}$ \\
\hline 1 & $\begin{array}{l}\text { H.A. Azis, M. } \\
\text { Taher, A.S. } \\
\text { Ahmed, } \\
\text { W.M.A.W. } \\
\text { Sulaiman, D. } \\
\text { Susanti, S.R. } \\
\text { Chowdhury, } \\
\text { Z.A. Zakaria } \\
\text { (2016) }\end{array}$ & $\begin{array}{l}\text { In vitro and In vivo wound } \\
\text { healing studies of methanolic } \\
\text { fraction of Centella asiatica } \\
\text { extract }\end{array}$ & $\begin{array}{l}\text { Pemberian } \\
\text { methanol } \\
\text { fraction (MF) } \\
\text { Centella asiatica } \\
\text { mempercepat } \\
\text { waktu } \\
\text { penyembuhan } \\
\text { secara signifikan }\end{array}$ & $\begin{array}{l}\text { Metanolic Fraction } \\
\text { (MF) 40\% merupakan } \\
\text { konsentrasi yang } \\
\text { memberikan efek paling } \\
\text { baik terhadap } \\
\text { penyembuhan luka }\end{array}$ \\
\hline 2 & $\begin{array}{l}\text { Chen-Zhen } \\
\text { Zhang, Jie Niu, } \\
\text { Yee-Song } \\
\text { Chong, Yan- } \\
\text { Fen Huang, } \\
\text { Yang Chu, } \\
\text { Sheng-Yang } \\
\text { Xie, Zhi-Hong } \\
\text { Jiang, Li-Hua } \\
\text { Peng (2016) }\end{array}$ & $\begin{array}{l}\text { Porous microspheres as } \\
\text { promising vehicles for the } \\
\text { topical delivery of poorly } \\
\text { soluble asiaticoside accelerate } \\
\text { wound healing and inhibit } \\
\text { scar formation in vitro \& in } \\
\text { vivo }\end{array}$ & $\begin{array}{l}\text { Pemberian } \\
\text { asiaticoside } \\
\text { meningkatkan } \\
\text { proses epitelisasi } \\
\text { dan sintesis } \\
\text { kolagen dalam } \\
\text { penyembuhan } \\
\text { luka }\end{array}$ & $\begin{array}{l}\text { Sediaan asiaticoside } \\
\text { solution dan } \\
\text { asiaticoside- } \\
\text { microsphere } \\
\text { mempercepat proses } \\
\text { penyembuhan luka }\end{array}$ \\
\hline 3 & $\begin{array}{l}\text { Somchai } \\
\text { Sawatdee, } \\
\text { Kanuengnit } \\
\text { Choochuay, } \\
\text { Wirot } \\
\text { Chanthorn, } \\
\text { Teerapol } \\
\text { Srichana } \\
\text { (2016) }\end{array}$ & $\begin{array}{l}\text { Evaluation of the topical } \\
\text { spray containing Centella } \\
\text { asiatica extract and its } \\
\text { efficacy on excision wounds } \\
\text { in rats }\end{array}$ & $\begin{array}{l}\text { Pemberian } \\
\text { ekstrak Centella } \\
\text { asiatica } \\
\text { menunjukan } \\
\text { aktivitas } \\
\text { penyembuhan } \\
\text { luka pada luka } \\
\text { eksisi dan luka } \\
\text { abrasi. }\end{array}$ & $\begin{array}{l}\text { Pemberian ekstrak } \\
\text { Centella asiatica dalam } \\
\text { sediaan semprotan } \\
\text { topikal mempercepat } \\
\text { proses penyembuhan } \\
\text { luka tanpa terjadinya } \\
\text { efek samping }\end{array}$ \\
\hline 4 & $\begin{array}{l}\text { Sung Giu Jin, } \\
\text { Kyung Soo } \\
\text { Kim, Abid } \\
\text { Mehmood } \\
\text { Yousaf, Dong } \\
\text { Wuk Kim, Sun } \\
\text { Woo Jang, Mi- } \\
\text { Won Son, } \\
\text { Young Hun } \\
\text { Kim (2015) }\end{array}$ & $\begin{array}{l}\text { Mechanical properties and in } \\
\text { vivo healing evaluation of a } \\
\text { novel Centella asiatica-loaded } \\
\text { hydrocolloid wound dressing }\end{array}$ & $\begin{array}{l}\text { Centella asiatica } \\
\text { mempercepat } \\
\text { proses epitelisasi } \\
\text { pada proses } \\
\text { penyembuhan } \\
\text { luka }\end{array}$ & $\begin{array}{l}\text { Centella asiatica dalam } \\
\text { bentuk sediaan } \\
\text { hidrokoloid } \\
\text { memperlihatkan proses } \\
\text { penutupan luka yang } \\
\text { lebih baik dibanding } \\
\text { produk komersial dan } \\
\text { kontrol }\end{array}$ \\
\hline
\end{tabular}




\begin{tabular}{|c|c|c|c|c|}
\hline No & $\begin{array}{l}\text { Peneliti dan } \\
\text { Tahun } \\
\text { Penelitian }\end{array}$ & Judul & $\begin{array}{l}\text { Efektivitas } \\
\text { Centella } \\
\text { asiatica (L.) } \\
\text { Urban } \\
\text { terhadap luka }\end{array}$ & $\begin{array}{l}\text { Sediaan Centella } \\
\text { asiatica (L.) Urban } \\
\text { terhadap luka }\end{array}$ \\
\hline 5 & $\begin{array}{l}\text { Donatella } \\
\text { Paolino, } \\
\text { Donato Cosco, } \\
\text { Felisa Cilurzo, } \\
\text { Elena } \\
\text { Trapasso, } \\
\text { Valeria M. } \\
\text { Morittu, } \\
\text { Christian Celia, } \\
\text { Massimo } \\
\text { Fresta (2012) }\end{array}$ & $\begin{array}{l}\text { Improved in vitro and in vivo } \\
\text { collagen biosynthesis by } \\
\text { asiaticoside-loaded } \\
\text { ultradeformable vesicles }\end{array}$ & $\begin{array}{l}\text { Pemberian } \\
\text { asiaticoside } \\
\text { meningkatkan } \\
\text { biosintesis } \\
\text { kolagen pada } \\
\text { proses } \\
\text { penyembuhan } \\
\text { luka }\end{array}$ & $\begin{array}{l}\text { Sediaan asiaticoside- } \\
\text { loaded ultradeformable } \\
\text { vesicles menunjukan } \\
\text { peningkatan biosintesis } \\
\text { kolagen yang lebih baik } \\
\text { dibanding asiaticoside } \\
\text { murni }\end{array}$ \\
\hline 6 & $\begin{array}{l}\text { Afnan Sh. } \\
\text { Ahmed, } \\
\text { Muhammad } \\
\text { Taher, Uttam } \\
\text { Kumar } \\
\text { Mandal, } \\
\text { Juliana Md } \\
\text { Jaffri, Deny } \\
\text { Susanti, } \\
\text { Syed } \\
\text { Mahmood, } \\
\text { Zainul } \\
\text { Amiruddin } \\
\text { Zakaria (2019) }\end{array}$ & $\begin{array}{l}\text { Pharmacological properties } \\
\text { of Centella asiatica hydrogel } \\
\text { in accelerating wound } \\
\text { healing in rabbits }\end{array}$ & $\begin{array}{l}\text { Asiaticoside } \\
\text { dapat } \\
\text { mempercepat } \\
\text { terjadinya proses } \\
\text { epitelisasi pada } \\
\text { penyembuhan } \\
\text { luka }\end{array}$ & $\begin{array}{l}\text { Asiaticoside dalam } \\
\text { bentuk sediaan } \\
\text { hydrogel mempercepat } \\
\text { penyembuhan luka } \\
\text { hingga 40\% lebih cepat } \\
\text { dibanding kontrol. }\end{array}$ \\
\hline 7 & $\begin{array}{l}\text { Juraiporn } \\
\text { Somboonwong, } \\
\text { Mattana } \\
\text { Kankaisre, } \\
\text { Boonyong } \\
\text { Tantisira, } \\
\text { Mayuree H } \\
\text { Tantisira } \\
\text { (2012) }\end{array}$ & $\begin{array}{l}\text { Wound healing activities of } \\
\text { different extracts of Centella } \\
\text { asiatica in incision and burn } \\
\text { wound models: an } \\
\text { experimental animal study }\end{array}$ & $\begin{array}{l}\text { Ekstrak Centella } \\
\text { asiatica dapat } \\
\text { meningkatkan } \\
\text { proses epitelisasi } \\
\text { dan keratinisasi } \\
\text { dalam } \\
\text { penyembuhan } \\
\text { luka insisi dan } \\
\text { luka bakar }\end{array}$ & $\begin{array}{l}\text { Ekstrak etil asetat } \\
\text { Centella asiatica } \\
\text { memperlihatkan efek } \\
\text { penyembuhan luka } \\
\text { paling baik }\end{array}$ \\
\hline 8 & $\begin{array}{l}\text { Chun-Hsu Yao, } \\
\text { Jen-Yu Yeh, } \\
\text { Yueh-Sheng } \\
\text { Chen, Ming- } \\
\text { Hsien Li, } \\
\text { Chiung-Hua } \\
\text { Huang (2015) }\end{array}$ & $\begin{array}{l}\text { Wound-healing effect of } \\
\text { electrospun gelatin } \\
\text { nanofibres containing } \\
\text { Centella asiatica extract in a } \\
\text { rat model }\end{array}$ & $\begin{array}{l}\text { Centella asiatica } \\
\text { dapat } \\
\text { meningkatkan } \\
\text { proses } \\
\text { pembentukan } \\
\text { kolagen dan } \\
\text { proliferasi sel } \\
\text { kulit dalam } \\
\text { proses } \\
\text { penyembuhan } \\
\text { luka. }\end{array}$ & $\begin{array}{l}\text { Pemberian Centella } \\
\text { asiatica dalam bentuk } \\
\text { sediaan serat nano } \\
\text { gelatin elektrospun } \\
\text { efektif mempercepat } \\
\text { proses penyembuhan } \\
\text { luka selama fase } \\
\text { inflamasi dan } \\
\text { proliferasi. }\end{array}$ \\
\hline
\end{tabular}

Berdasarkan analisis terhadap 8 artikel yang telah di-review, hasil yang didapatkan adalah sebagai berikut. Pemberian methanol fraction Centella asiatica dengan konsentrasi $40 \%$, $10 \%$, dan 2,5\% meningkatkan persentase kontraksi luka dibanding dengan luka yang tidak dirawat. Fraksi metanol $40 \%$ merupakan konsentrasi fraksi yang memberikan efek paling baik terhadap penyembuhan luka dibanding dengan MF 10\% dan MF 2,5\%.9 Asiaticoside solution 
dan asiaticoside-microsphere efektif terhadap penyembuhan luka ditandai dengan penutupan luka yang lebih cepat, deposisi kolagen yang teratur, dan pembentukan pembuluh darah baru. 10

Pemberian ekstrak Centella asiatica yang diberikan dalam bentuk sediaan semprotan topikal memperlihatkan penutupan luka yang lebih cepat dan tindak menimbulkan efek samping iritasi dan eritema.11 Penutupan luka yang ditutup dengan produk komersial (duoderm) dan HCD (hydrocolloid dressing) yang mengandung Centella asiatica menunjukkan efektif yang sama terhadap penyembuhan luka sayat maupun luka abrasi.12 Pemberian asiaticoside-loaded ultradeformable vesicle fraksi molar natrium kolat 0,2 dapat mempercepat proses penyembuhan luka melalui peningkatan biosintesis kolagen pada hari ke-7, 14, dan 28 sebesar $\sim 105 \% .13$

Asiatikosida-hidrogel memperlihatkan penyembuhan luka yang paling cepat, ditandai dengan periode epitelisasi yang lebih singkat dibanding luka yang tidak diobati maupun dengan pemberian krim komersial (Madecassol krim).14 Ekstrak Centella asiatica memperlihatkan proses epitelisasi dan keratinisasi yang optimal pada luka bakar tanpa disertai nekrosis atau peradangan. Ekstrak Centella asiatica juga dapat meningkatkan kekuatan tarikan (tensile strength) pada proses penutupan luka sayat secara signifikan pada semua kelompok yang diberi ekstrak Centella asiatica.15 Pemberian serat nano gelatin elektrospun yang mengandung ekstrak Centella asiatica efektif menyembuhkan luka ditandai dengan peningkatan deposisi kolagen dan sedikit peningkatan jumlah kapiler di area luka dibanding dengan perawatan lainnya.

\section{Diskusi}

Hasil analis penelitian dari seluruh artikel yang telah dikaji menunjukkan bahwa Centella asiatica beserta zat aktif yang terkandung di dalamnya berperan dalam proses penyembuhan luka. Hasil penelitian Sawatdee dkk.11 memperlihatkan bahwa asiaticoside sebagai salah satu zat aktif Centella asiatica, dapat menstimulasi regenerasi epidermis dengan mengaktifkan lapisan sel malphigian dan keratinisasi serta meningkatkan penyembuhan luka. Aktivitas asiaticoside yang paling penting adalah meningkatkan sintesis kolagen.

Penelitian Somboonwong dkk.15 memperlihatkan bahwa zat aktif asiaticoside dapat menginduksi aktivasi sintesis kolagen tipe I dari sinyal Smad reseptor TGF beta I kinaseindependen pada sel fibroblas dan juga sebagai antioksidan. Adapun asiatic acid yang menginduksi ekspresi TNFAIP6 terlibat dalam peningkatan matriks ekstraseluler dan sintesis kolagen, seperti halnya madecassoside yang juga dapat meningkatkan sintesis kolagen.15

Sediaan asiaticoside solution dan asiaticoside-microsphere dalam pemberian ekstrak Centella asiatica pada penelitian Zhang dkk.10 secara histopatologi menunjukkan efektivitas dalam proses deposisi serat kolagen. Susunan beberapa serat kolagen yang terbentuk dalam penyembuhan luka terlihat menjadi lebih teratur disertai dengan pembentukan pembuluh darah baru yang berperan pada peningkatan regenerasi vaskular.10 Peningkatan deposisi kolagen dan jumlah kapiler di area luka juga terlihat pada penggunaan EGC pada penelitian Yao dkk.6

Berdasar atas hasil kajian artikel dalam penelitian ini diperoleh adanya beberapa jenis sediaan yang dapat digunakan untuk meningkatkan efektivitas Centella asiatica, di antaranya sediaan ultradeformable vesicle yang mengandung asiaticoside yang diteliti oleh Paolino dkk.13 Hasil penelitian tersebut menunjukkan bahwa sediaan ultradeformable vesicle dapat meningkatkan permeasi asiaticoside. Peningkatan permease tersebut menyebabkan penetrasi langsung asiaticoside ke kulit sehingga meningkatkan biosintesis kolagen secara signifikan.13

Penelitian Zhang dkk.10 terhadap sediaan asiaticoside-microsphere memperlihatkan hasil yang baik pada proses penyembuhan luka. Microsphere diduga bertindak sebagai pengangkut obat dan juga reservoir untuk melindungi obat dari proses inaktivasi dan meningkatkan penyerapannya. Microsphere berpori adalah spons kecil yang terdiri atas banyak sekali interkoneksi rongga dengan permukaan berpori. Sifat dan struktur lubang microsphere berpori memunculkan potensi dalam penggabungan hidrofilik dan lipofilik molekul, serta meningkatkan stabilitas obat. Microsphere berpori direkomendasikan sebagai bentuk sediaan ideal yang dapat meningkatkan kelarutan dan mengontrol pelepasan asiaticoside sehingga dapat mengoptimalkan penyerapan asiaticoside dalam tubuh. 
Pembalut hidrokoloid sering digunakan dalam penyembuhan luka. Berbagai elastomer, perekat dan hidrofilik polimer dalam balutan ini dilekatkan pada lembaran tipis semipermeabel untuk menghasilkan balutan datar dan membentuk gel setelah kontak dengan eksudat luka sehingga memudahkan penyembuhan luka.12 Penelitian yang dilakukan oleh Jin dkk.12 menunjukan bahwa pembalut hidrokoloid yang mengandung Centella asiatica dapat digunakan sebagai pengobatan luka sayat.

Ekstrak Centella asiatica dalam sediaan hidrogel memberikan hasil yang baik sesuai dengan hasil penelitian Ahmed dkk.14 Sediaan hidrogel dapat menjadi bahan ideal pembalut luka karena dapat melindungi luka dari infeksi sekunder, mempercepat penyembuhan luka, mengurangi nekrosis dasar luka, mencegah terjadinya trauma sekunder pada regenerasi jaringan setelah pembalut luka dilepas, tidak menempel, dan tidak menyebabkan iritasi.14

Penelitian Yao dkk.6 memperlihatkan peningkatan efektivitas ekstrak Centella asiatica dalam penyembuhan luka melalui penggunaan serat nano gelatin elektrospun. Serat nano gelatin elektrospun merupakan balutan berpori yang memungkinkan permeasi oksigen tinggi sehingga dapat mempromosikan respirasi sel, regenerasi kulit, retensi kelembapan, dan penyerapan eksudat yang lebih efisien. Penggunaan sediaan serat nano gelatin elektrospun bagi ekstrak Centella asiatica dapat mencegah penempelan balutan pada luka, menyerap eksudat, dan mempertahankan konsentrasi optimal ekstrak Centella asiatica dalam kulit.6

Siklodekstrin adalah oligosakarida siklik dengan permukaan luar hidrofilik dan rongga sentral hidrofobik. Turunan dari siklodekstrin mengandung hidrofilik yang dimodifikasi, yaitu HP-b-CD (Hidroksipropil-b-siklodekstrin) yang dapat meningkatkan kelarutan obat. Penelitian Sawatdee dkk.9 membuktikan bahwa semprotan topikal dengan kandungan HP-b-CD dapat meningkatkan kelarutan serta penarikan senyawa aktif dari ekstrak Centella asiatica dalam formulasi.

Penelitian Azis dkk.9 menunjukkan bahwa methanol fraction Centella asiatica memiliki khasiat penyembuhan luka. Methanol fraction asiaticoside pada konsentrasi standar 2,4\% sudah mulai menunjukkan kemampuan migrasi dan proliferasi sel fibroblas serta keratin yang berkaitan dengan kandungan terpenoid berupa asiaticoside, asiatic acid, dan madecassicoside. Kandungan terpenoid lebih banyak ditemukan dalam fraksi etil asetat dan methanol fraction pada penelitian ini. Hal tersebut disebabkan karena adanya ikatan hidrogen antara gugus hidroksil terpenoid dengan etil asetat dan etanol yang mengakibatkan senyawa tersebut tertarik oleh etil asetat dan metanol.

\section{Kesimpulan}

Centella asiatica (L.) Urban efektif terhadap penyembuhan luka pada hewan coba. Beberapa sediaan terbukti meningkatkan efektivitas Centella asiatica (L.) Urban dalam penyembuhan luka, yaitu ekstrak, methanol fraction, semprotan topical, ultradeformable vesicle, microsphere, dan balutan luka (serat nano gelatin elektrospun, hidrogel, dan hydrocolloid dressing).

\section{Acknowledge}

Penulis mengucapkan terima kasih kepada seluruh pihak yang telah membantu dalam penyusunan artikel ini.

\section{Daftar Pustaka}

[1] Primadina N, Basori A, Perdanakusuma DS. Proses penyembuhan luka ditinjau dari aspek mekanisme seluler dan molekuler. Qanun Med - Med J Fac Med Muhammadiyah Surabaya. 2019;3(1):31.

[2] Pratiwi D. Uji evaluasi sediaan krim esktrak etanol daun mengkudu sebagai obat penyembuh luka. Indones J Med. 2019;6(1):3-7.

[3] Powers JG, Higham C, Broussard K, Phillips TJ. Wound healing and treating wounds chronic wound care and management. J Am Acad Dermatol. 2016;74(4):607-25. [diunduh 25 Januari 2020]. Tersedia dari: http://dx.doi.org/10.1016/j.jaad.2015.08.070 
[4] Sutardi S. Kandungan bahan aktif tanaman pegagan dan khasiatnya untuk meningkatkan sistem imun tubuh. Jurnal Litbang Pertanian. 2017;35(3):121.

[5] Lisiswanti R, Fiskasari SR. Manfaat pegagan (Centella asiatica) terhadap pengobatan penyakit Alzheimer benefits of Pegagan (Centella asiatica) in the treatment of Alzheimer's disease. J Kedokt Kesehat. 2017;6:132-6.

[6] Yao CH, Yeh JY, Chen YS, Li MH, Hyang CH. Wound-healing effect of electrospun gelatin nanofibres containing centella asiatica extract in a rat model. J Tissue Eng Regen Med. 2015;19:213.

[7] Widianingtyas D, Wihastuti T A, Setijowati N. Pengaruh perawatan dengan ekstrak daun pegagan (Centella asiatica) dalam mempercepat penyembuhan luka bakar derajat 2 dangkal pada tikus putih (Rattus norvegicus). Maj Kes FKUB. 2014;1:223-7.

[8] Harsa IMS. Efek pemberian ekstrak daun pegangan (centella asiatica) terhadap penyembuhan luka sayat pada tikus putih jantan (rattus novergicus) galur wistar. J Ilm Kedokt Wijaya Kusuma. 2020 Maret;9(1):21-27

[9] Azis HA, Taher M, Ahmed AS, Sulaiman WMAW, Susanti D, Chowdhury SR, dkk. In vitro and in vivo wound healing studies of methanolic fraction of Centella asiatica extract. South African J Bot. 2017;108:163-74.

[10] Zhang CZ, Niu J, Chong YS, Huang YF, Chu Y, Xie SY, dkk. Porous microspheres as promising vehicles for the topical delivery of poorly soluble asiaticoside accelerate wound healing and inhibit scar formation in vitro \& in vivo. Eur J Pharm Biopharm. 2016;109:113.

[11] Sawatdee S, Choochuay K, Chanthorn W, Srichana T. Evaluation of the topical spray containing Centella asiatica extract and its efficacy on excision wounds in rats. Acta Pharm. 2016;66(2):233-44.

[12] Jin SG, Kim KS, Yousaf AM, Kim DW, Jang SW, Son MW, dkk. Mechanical properties and in vivo healing evaluation of a novel Centella asiatica-loaded hydrocolloid wound dressing. Int J Pharm. 2015;490(1-2):240-7.

[13] Paolino D, Cosco D, Cilurzo F, Trapasso E, Morittu VM, Celia C, dkk. Improved in vitro and in vivo collagen biosynthesis by asiaticoside-loaded ultradeformable vesicles. J Control Release. 2012;162(1):143-51.

[14] Sh Ahmed A, Taher M, Mandal UK, Jaffri JM, Susanti D, Mahmood S, dkk. Pharmacological properties of Centella asiatica hydrogel in accelerating wound healing in rabbits. BMC Complement Altern Med. 2019;19(1):1-7.

[15] Somboonwong J, Kankaisre M, Tantisira B, Tantisira MH. Wound healing activities of different extracts of Centella asiatica in incision and burn wound models: an experimental animal study. BMC Complement Altern Med. 2012;12:2-7. 